Mohsen Ehteshami (Moḥsen Eḥtešāmī). Logo-hā-ye mațbū'āt-e dowre-ye qājār / Logos of Iranian printed media in the Qajar period

\title{
Iván Szántó
}

\section{(2) OpenEdition \\ 1 Journals}

Electronic version

URL: http://journals.openedition.org/abstractairanica/41882

DOI: 10.4000/abstractairanica.41882

ISSN: 1961-960X

Publisher:

CNRS (UMR 7528 Mondes iraniens et indiens), Éditions de l'IFRI

\section{Electronic reference}

Iván Szántó, « Mohsen Ehteshami (Mohsen Ehtešāmī). Logo-hā-ye mațbū'āt-e dowre-ye qājār / Logos of Iranian printed media in the Qajar period ", Abstracta Iranica [Online], Volume 34-35-36 | 2017, document 15, Online since 30 December 2016, connection on 26 September 2020. URL : http:// journals.openedition.org/abstractairanica/41882; DOI : https://doi.org/10.4000/abstractairanica. 41882

This text was automatically generated on 26 September 2020.

Tous droits réservés 


\title{
Mohsen Ehteshami (Moḥsen Eḥtešāmī). Logo-hāa-ye mațbū' āt-e dowre-ye qājār / Logos of Iranian printed media in the Qajar period
}

\author{
Iván Szántó
}

\section{REFERENCES}

Mohsen Ehteshami (Moḥsen Eḥtešāmī). Logo-hā-ye mațbū'āt-e dowre-ye qājār / Logos of Iranian printed media in the Qajar period. Tehran, 1391/2012, 214 p., over 600 ill.

1 Filling a hitherto hardly recognised gap, this compact volume offers a register of over five hundred newspapers, gazettes, and other periodicals, from the beginning of commercial printing in Iran (1233 h.q. / 1816 c.e.) to the end of the Qajar dynasty. What gives this compilation a heightened significance is that for the first time it surveys them based on their visual layout, as opposed to their literary content, informative value, or political agenda. Accordingly, the bulk of the volume comprises thumbnailsize images of the "logo" (one would prefer to call it as masthead or nameplate) of each publication, arranged in alphabetical order. Each image is supplemented by a short checklist which includes the general alignment of the respective periodical, editors' name, foundation date, publication frequency, etc. This is why the book comes in handy for reference and comparative analysis and may be used in parallel with standard works on the subject, including those by Mohammad Șadr-Hāšemī and others. The author does not fail to admit that his catalogue is not a fully comprehensive database: titles which were unavailable for photographic reproduction were omitted, just like the full range of logos of the same publication, a limitation which was dictated by the shortage of space. Nevertheless, the rhythmic flow of hundreds of headpieces still impresses on the viewer their rich and so-far badly underestimated variety. Given that the alphabetic order in which the catalogue is presented is just one possible way to 
organise the material, the reader will be pleased to find an introductory chapter about other options (i.e., distinguishing between script-only and pictorial mastheads, as well as the printing techniques of lithography and typesetting). Reflecting a recent tendency in Qajar studies, this volume emphasises the need for a technological approach to early Persian journalism instead of an ideological one. Through the rich visual material, it demonstrates the high degree of creativity manifest in early Iranian graphic design. In this respect, the book is a tribute to these little-known printercalligraphers: they formed a wholly new community of professionals which took the stage to align traditional Iranian visual media with the imported infrastructure of industrialisation and shaped the production of texts and images in an increasingly competitive environment of cultural consumerism.

\section{AUTHORS}

\section{IVÁN SZÁNTÓ}

Eötvös Loránd University [ELTE], Budapest/Austrian Academy of Sciences [ÖAW], Vienne 